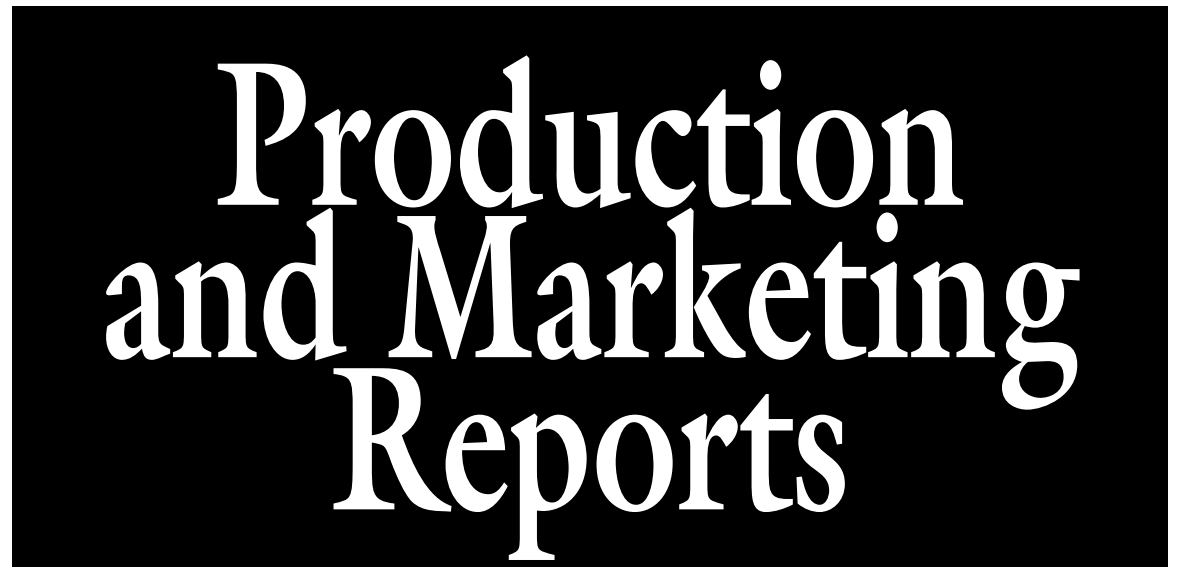

\section{Supporting Successful Transition to the Fresh Market: Research and Extension Needs of Pacific Northwest Strawberry Growers}

\author{
Zongyu $\mathrm{Li}^{1}$, R. Karina Gallardo ${ }^{2}$, Wendy Hoashi-Erhardt ${ }^{3}$, \\ Vicki A. McCracken ${ }^{1}$, Chengyan Yue ${ }^{4}$, \\ and Lisa Wasko DeVetter ${ }^{5}$
}

AdDitional INDEX WORDs. econometric modeling, Fragaria $\times$ ananassa, grower survey, trait clusters, trait prioritization

Summary. Pacific Northwest North America (PNW) strawberry (Fragaria $\times$ ananassa) growers are transitioning away from the processing to fresh-market sector in response to changes in local and regional markets. However, many of the regional cultivars bred for the PNW were not developed for the fresh market. There is a need to gain a better understanding of growers' priority traits and their relative importance to enable breeders, researchers, and extension specialists to better serve this growing industry. The objective of this study was to provide such information on strawberry genetic traits of importance for the changing strawberry industry in the PNW with an emphasis on fresh-market production. Six surveys were administered to 32 growers representing $\approx 53 \%, 23 \%$, and $15 \%$ of the total strawberry acreage in Oregon, Washington, and British Columbia, Canada, respectively. Growers ranked the relative importance of five plant and fruit traits, including fruit quality, disease resistance/tolerance, insect pest resistance/tolerance, plant stress tolerance, and other plant factors. Information about target markets, marketing channels, and general grower characteristics were also obtained. Whereas overall responses differed among the surveyed locations, fruit quality was considered the most important trait across all locations, with disease resistance/tolerance as the second most important. Specific fruit quality traits of importance were external appearance free of defects, skin color, size, sweetness, firmness, and flavor, whereas phytonutrients, seed color, and low drip loss after freezing and thawing were less important. Plant stress tolerance was identified as less important for strawberry growers in all locations. Results also showed many growers have already or are in the process of transitioning to the fresh market. Information obtained from this survey can be leveraged to target important breeding traits for fresh-market strawberry breeders within the PNW. Results also suggest priority areas of synergistic research and outreach activities to help growers achieve high fruit quality while managing diseases for fresh-market producers.

A $n$ efficient food production sector adapts to consumer preferences for crops and food products. One noteworthy driver of consumer purchases is the recent increased interest and demand for local foods. Some regard local food as more environmentally friendly; others view local food as fresher, safer, healthier, and supportive of community (Carroll et al., 2013; Feldmann and Hamm, 2015; Zepeda and Leviten-Reid, 2004).

Strawberry growers in the western parts of Pacific Northwest North America (comprising Oregon, Washington, and British Columbia, Canada) use similar production methods and cultivars and face similar climates. They have also been responding and adapting to changing market conditions. Historically, strawberry produced in the PNW was targeted for the processing market. However, demand for processed strawberry has declined considerably over the last several years, and this is reflected in crop production. For example, production of processed strawberry in Washington and Oregon decreased from 334,000 cwt in 2008 to $171,800 \mathrm{cwt}$ in 2016 [U.S. Department of Agriculture (USDA), 2018b]. Meanwhile, freshmarket strawberry has grown in importance. During the last 10 years, the value of fresh strawberry grown in Washington and Oregon increased by $142 \%$, from a combined value of $\$ 129.5 / \mathrm{cwt}$ in 2006 to $\$ 313 / \mathrm{cwt}$ in 2016, the last year for which these data are available (USDA, 2007, 2018a). Similarly, demand for fresh strawberry continues to grow across the United States: between 1980 and 2017 , the annual per capita consumption of processed strawberry increased from 1.2 to $1.8 \mathrm{lb}$, an increase of $50 \%$, whereas fresh strawberry consumption increased from 2.0 to $8.4 \mathrm{lb}$, an increase of $32 \mathrm{l} \%$ (USDA, 2018a).

Fresh strawberry represents a high-value opportunity for PNW growers, who would benefit from the expansion of direct marketing channels such as farmers' markets. Ostrom and Donovan (2013) found that berries were a top fresh product that Washington farmers' market managers would like to offer at their markets. To adjust to these expanding markets, PNW strawberry growers will need to adapt their production practices, including their cultivar choices, to improve the availability of fruit for these new marketing channels.

This study evaluates PNW strawberry growers' preferences for selected genetic traits in the context of 
investing in new strawberry cultivars. Only some strawberry cultivars are suitable for both fresh and processing markets; most are suitable for one or the other (Finn et al., 2014). Choice of cultivar is influenced by the environmental conditions of the production region. For example, freshmarket strawberry cultivars widely planted in California production regions are not necessarily well suited to the cooler climates of western Oregon and Washington (Finn et al., 2014). In fact, only one cultivar [Albion, which is from California (Shaw and Larson, 2005)] is currently leading fresh-market strawberry production in the PNW, and growers have expressed a desire for more diverse and adapted cultivars (personal observation). For PNW strawberry growers to successfully transition to the fresh market, they need new strawberry cultivars adapted to their growing conditions and with fruit characteristics suited to the fresh market.

Limited research has addressed the importance of strawberry attributes to various supply chain members. A handful of these studies focused on final consumer preferences for

Received for publication 22 Apr. 2019. Accepted for publication 14 June 2019.

Published online 7 August 2019.

${ }^{1}$ School of Economic Sciences, Washington State University, P.O. Box 646210, Hulbert Hall, Pullman, WA 99164

${ }^{2}$ School of Economic Sciences, IMPACT Center, Washington State University Puyallup Research and Extension Center, 2606 W. Pioneer Avenue, Puyallup, WA 98371

${ }^{3}$ Department of Horticulture, Washington State University Puyallup Research and Extension Center, 2606 W. Pioneer Avenue, Puyallup, WA 98371

${ }^{4}$ Department of Horticultural Science and Department of Applied Economics, University of Minnesota, Twin Cities, 1970 Folwell Avenue, St. Paul, MN 55108

${ }^{5}$ Department of Horticulture, Washington State University Northwestern Washington Research and Extension Center, 16650 State Route 536, Mount Vernon, WA 98273

Funding for this project was provided by the USDA National Institute of Food and Agriculture Specialty Crop Research Initiative project "RosBREED: Combining Disease Resistance with Horticultural Quality" (2014-51181-22378) and by the Washington State Department of Agriculture Specialty Crop Block Grant program. Additional assistance with survey distribution was provided by Chris Benedict at Washington State University and Tom Peerbolt and Julie Pond at Peerbolt Crop Management.

L.W.D. is the corresponding author. E-mail: lisa. devetter@wsu.edu.

This is an open access article distributed under the CC BY-NC-ND license (https://creativecommons.org/ licenses/by-nc-nd/4.0/).

https://doi.org/10.21273/HORTTECH04389-19 strawberry attributes. Colquhoun et al. (2012) found that freshness, flavor, texture, fruit size, and color were important attributes for U.S. consumers, and this research was focused on California and Florida cultivars. Wang et al. (2016) identified three groups of U.S. consumers that were heterogeneous in their preferences for external and internal strawberry quality attributes, indicating that ideal strawberry characteristics differ across different market segments.

One study focused on marketing intermediaries' preferences found that size, flavor, and firmness were important strawberry attributes for packing and shipping operations (Gallardo et al., 2015). Similarly, Yue et al. (2014) found that U.S. strawberry growers as a group identified fruit firmness, flavor, and shelf life at retail as important traits for successful strawberry cultivars. They also found that California and Florida strawberry growers ranked fruit flavor as less important than growers from Michigan and Oregon, suggesting that growers' preferences are influenced by the differences in market situations in each state.

From the perspective of breeding programs, one study found that phytonutrient content, abiotic resistance, plant habit, disease and pest resistance, and appearance were the five most important trait clusters for strawberry breeding programs (Gallardo et al., 2012). The likelihood of selecting for resistance to diseases and pests as a trait cluster for strawberry was higher than the likelihood of selecting for abiotic resistance, yield, and phytonutrient content but lower than the likelihood of selecting for appearance. Yue et al. (2012) found that breeding objectives related to consumer preferences, intended end-use markets, and available market price premiums were of lower priority for strawberry breeding programs than apple (Malus $\times$ domestica), peach (Prunus persica), and sweet cherry (Prunus avium) breeding programs. Strawberry breeders rated feedback from nurseries and other colleagues as more important than feedback from consumers or growers when setting priorities for breeding programs. Strawberry breeders were more challenged by time limitations but less challenged by availability of genetic material, trait heritability, genetic variation, and lack of facilities than breeders of apple, peach, and sweet cherry (Yue et al., 2012).

The goal of this study was to provide information useful to breeders, extension specialists, and other research professionals about important strawberry genetic traits for the changing strawberry industry in the PNW, with an emphasis on fresh-market production. Identification of priority traits with maximum impact to the industry will inform and lead to more efficient and impactful breeding programs for this important regional crop. This study also adds to previous literature by comprehensively investigating plantand fruit-related genetic traits that would make the ideal strawberry cultivars from the perspective of PNW growers.

\section{Materials and methods}

Data collection. Surveys were conducted at six PNW small fruit and horticultural grower events between Nov. 2017 and Feb. 2018. A total of 32 responses were obtained. Only individuals who were farm owners, lessees, managers, or any of these and who had final responsibility for decisions concerning adoption of new strawberry cultivars were eligible to complete the survey. Events where the survey was administered included 1) Fresh Market Strawberry Workshop in Woodburn, OR; 2) PNW Plant Propagators' meeting in Puyallup, WA; 3) Washington Small Fruit Conference in Lynden, WA; 4) North Willamette Horticultural Society meeting in Canby, OR; 5 ) Lower Mainland Horticultural Improvement Association Growers' Short Course in Abbotsford, BC; and 6) Oregon Strawberry Commission Annual Meeting in Aurora, OR. The

\begin{tabular}{llll}
\hline $\begin{array}{l}\text { Units } \\
\begin{array}{l}\text { To convert U.S. to SI, } \\
\text { multiply by }\end{array}\end{array}$ & U.S. unit & SI unit & $\begin{array}{l}\text { To convert SI to U.S., } \\
\text { multiply by }\end{array}$ \\
\hline 0.4047 & $\mathrm{acre}(\mathrm{s})$ & $\mathrm{ha}$ & 2.4711 \\
45.3592 & $\mathrm{cwt}$ & $\mathrm{kg}$ & 0.0220 \\
0.4536 & $\mathrm{lb}$ & $\mathrm{kg}$ & 2.2046
\end{tabular}


Table 1. Strawberry fruit and plant clusters and associated traits addressed in a survey of strawberry growers in Pacific Northwest North America in 2017-18.

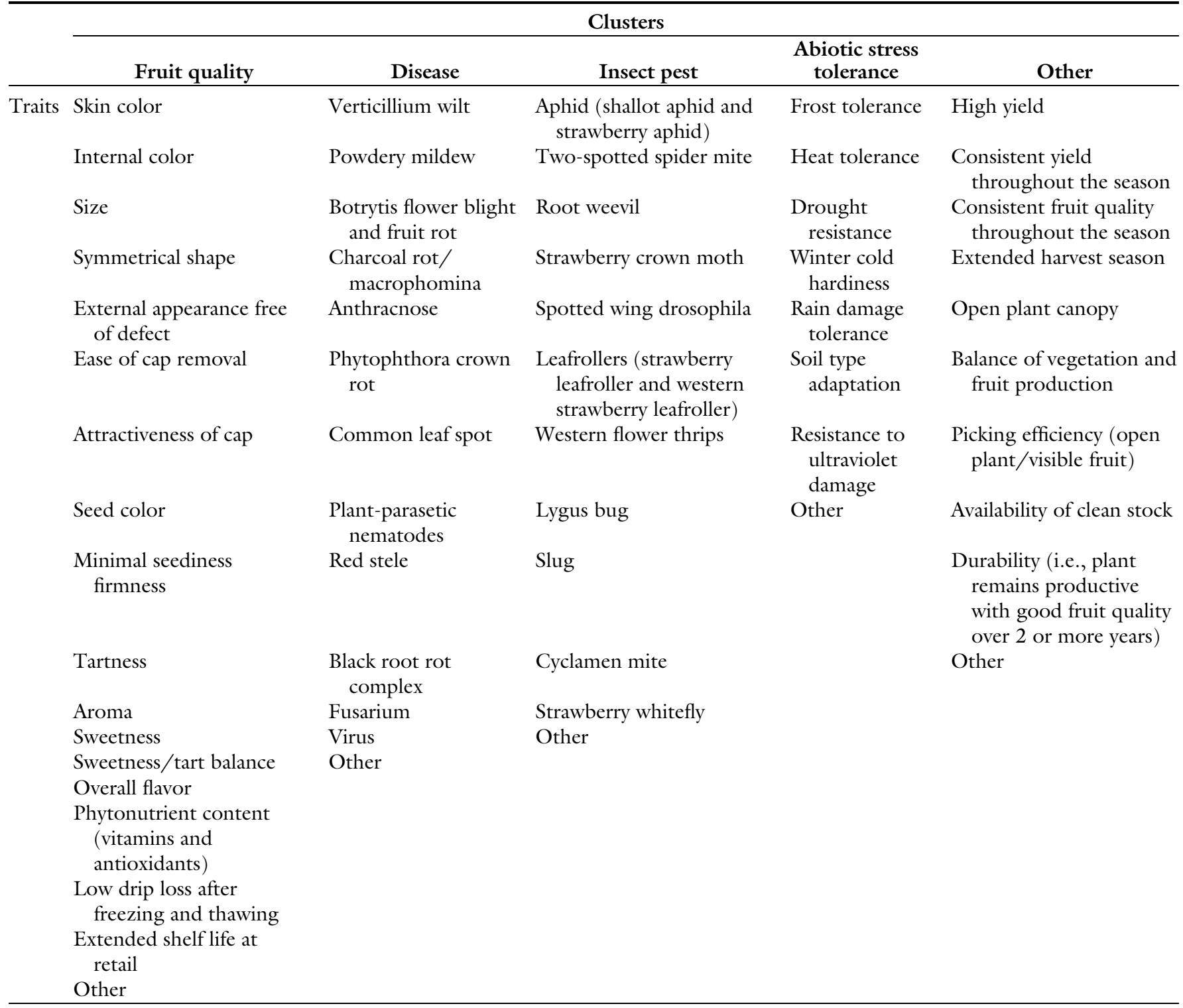

survey contained questions about target markets and marketing channels used for strawberry, and general grower and operation characteristics. We presented five clusters of plant and fruit traits (fruit quality, disease resistance/tolerance, insect pest resistance/tolerance, plant stress tolerance, and other plant factors), each of which included a number of traits that had been identified in consultation with PNW strawberry breeders, extension educators, industry representatives, and growers. Specific clusters and associated traits are presented and described in Table 1.

Within each trait cluster, growers were asked to choose the most and least important traits. For example, in the fruit quality cluster, growers were asked to identify the five most and the five least important traits among 19 fruit quality traits. The most important traits were later assigned the number 19, the second-most important traits were assigned the number 18 , and so on. If the grower considered a trait to be least important, it was assigned the number 1 , the second least important trait was assigned the number 2 , and so on. Traits that were not selected as either most or least important (the remaining 9 traits) were considered neutral choices and assigned the median value for the trait cluster (i.e., 10 for the fruit quality cluster, which had 19 levels). The number assigned to the neutral choice varied across trait clusters as each cluster had a different number of traits. In addition to ranking traits within clusters, respondents were asked to rank the five trait clusters by importance.

An econometric approach was taken to identify traits of importance to strawberry growers in their selection of cultivars. Based on Lancaster's (1966) model of consumer choice, consumers are assumed to derive utility from a good's attributes. Here, we assume that strawberry grower $i$ derives utility $U_{i j}$ from growing strawberry cultivars with specific fruit and plant traits $j$. We further assume that such utility is not observable but that the grower trait ranking, 
$y_{i j}=1,2, \ldots, n$, is observable and can be used as a proxy for $U_{i j}$. The utility function of grower $i$ from trait $j$ in one of six trait clusters can be expressed as

$$
U_{i j}=\partial_{j} x_{j i}+\varepsilon_{j i}
$$

where $\partial_{j}$ is a grower's marginal utility from growing a strawberry cultivar with traits $x_{j}$ and $\varepsilon_{i j}$ is assumed to follow a normal distribution. An ordered probit model was used to estimate the coefficients because $y_{i j}$ (the response variable) is discrete and ordinal (Greene and Hensher, 2008):

$$
y_{i j}=\left\{\begin{array}{cc}
1 & \text { if } U_{0}<U_{i j}<U_{1} \\
2 & \text { if } U_{1}<U_{i j}<U_{2} \\
3 & \text { if } U_{2}<U_{i j}<U_{3} \\
\vdots & \vdots \\
N & \text { if } U_{N-1}<U_{i j}
\end{array}\right.
$$

The probability of each ordinal outcome for grower $i$ is:

$$
\begin{aligned}
p_{i j} & =p\left(y_{i j}=n\right)=p\left(U_{\mathrm{n}-1}<U_{i j}<U_{\mathrm{n}}\right) \\
& =p\left(U_{\mathrm{n}-1}<\partial_{j} x_{j i}+\varepsilon_{j i}<U_{\mathrm{n}}\right) \\
& =p\left(U_{\mathrm{n}-1}-\partial_{j} x_{j i}<\varepsilon_{j i}<U_{\mathrm{n}}-\partial_{j} x_{j i}\right) \\
& \left.=\Phi\left(U_{\mathrm{n}}-\partial_{j} x_{j i}\right)-\Phi\left(U_{\mathrm{n}-1}-\partial_{j} x_{j i}\right)\right)
\end{aligned}
$$
tion is:

Then, the log-likelihood func-

$$
\ln \mathrm{L}=\sum_{i=1}^{I} \sum_{j=1}^{N} \ln \left(\Phi_{i j}-\Phi_{i j-1}\right)
$$

where maximum likelihood estimation is used to estimate estimates for $\partial_{j}$. Within each cluster, the traits were coded as a set of indicator variables and the estimated coefficient values were interpreted as the importance of each trait relative to the trait excluded explicitly in estimation.

Greene and Hensher (2008) used this model to determine the importance of product attributes. A rank-ordered probit was not used here because the respondents ranked ordered only their most important traits and their least important traits, resulting in not all respondents ranking the same set of traits. In addition, the traits studied are independent and do not share common underlying characteristics (which themselves can be ranked), which is usually the focus of a rank-ordered analysis.

It is assumed that growers' preferences for plant genetic traits are related to their specific growing location within PNW because of differences in production (e.g., climate and soil) and marketing (e.g., proximity to markets) conditions. Hence, we estimated the regression separately for each growing location (i.e., Washington, Oregon, and British Columbia). At the more aggregated level of trait clusters, we did not assume overall differences in preferences by growing location but allowed for differences across regions related to their overall cluster rankings. Therefore, we estimated a combined model with all observations, including interaction terms between farmers' growing location and ranking of each trait cluster. For this model, British Columbia was used as the base region to avoid perfect multicollinearity in estimation. The coefficients for statistically significant interactions were interpreted as the ranked importance of the cluster by growers in the specific region relative to its importance for British Columbia growers.

\section{Results and discussion}

GROWER AND FARM CHARACTERISTICS. Of the 32 growers who responded, 16 were from Oregon, 10 from Washington, and 6 from British Columbia. The acreage of these sampled growers relative to their farm location suggests that the sample represents $50 \%$ of total Oregon strawberry acreage, $28 \%$ of total Washington strawberry acreage, and $15 \%$ of total British Columbia strawberry acreage (British Columbia Strawberry Growers Association, 2019; USDA, 2019). Table 2 presents the summary statistics of grower and farm characteristics by farm location, and a weighted mean was calculated using the median point of the categories. Concerning the main target market for strawberry, the main target for all British Columbia growers was fresh market, which was higher than that for Washington growers (75\% fresh market) and Oregon growers $(62.5 \%$ fresh market).

Table 2. Summary statistics of farm and grower characteristics based on surveys of strawberry growers in Pacific Northwest North America in 2017-18 $(n=32)$.

\begin{tabular}{lcccc}
\hline & $\begin{array}{c}\text { British } \\
\text { Columbia }\end{array}$ & Oregon & Washington & All \\
\hline Main target market & & & & \\
Fresh (\%) & 100 & 62.5 & 75 & 72.4 \\
Processing (\%) & 0.0 & 37.5 & 25 & 27.6 \\
Observations (no.) & 5 & 16 & 8 & 29 \\
Change the market & & & & \\
Same (\%) & 50 & 92.9 & 75 & 80.8 \\
$<50 \%(\%)$ & 50 & 7.1 & 25 & 19.2 \\
$>50 \%$ (\%) & 0.0 & 0.0 & 0.0 & 0.0 \\
Observations (no.) & 4 & 14 & 8 & 26 \\
Strawberry farm size & & & & \\
<5 acres (\%) & 33.3 & 25 & 30 & 28.2 \\
$5-14$ acres (\%) & 16.7 & 31.3 & 30 & 28.2 \\
15-24 acres (\%) & 33.3 & 0.0 & 10 & 9.4 \\
25-49 acres (\%) & 16.7 & 31.3 & 10 & 21.9 \\
$50-99$ acres (\%) & 0.0 & 6.3 & 10 & 6.3 \\
100-249 acres (\%) & 0.0 & 0.0 & 10 & 3 \\
250-499 acres (\%) & 0.0 & 0.0 & 0.0 & 0.0 \\
$>500$ acres (\%) & 0.0 & 6.3 & 0.0 & 3 \\
Observations (no.) & 6 & 16 & 10 & 32 \\
Weighted mean (acres) & 15.1 & 70.3 & 34.2 & 48.4 \\
Years in the strawberry operation & in a decision-making position & & \\
1-5 years (\%) & 20 & 25 & 0.0 & 17.3 \\
6-10 years (\%) & 0.0 & 6.3 & 25 & 10.3 \\
11-15 years (\%) & 0.0 & 18.8 & 0.0 & 10.3 \\
16-19 years (\%) & 0.0 & 0.0 & 12.5 & 3.5 \\
$>20$ years (\%) & 80 & 50 & 62.5 & 58.6 \\
Observations (no.) & 5 & 16 & 8 & 29 \\
Weighted mean (years) & 20.6 & 16.2 & 19.8 & 17.9 \\
\hline
\end{tabular}

${ }^{\mathrm{z}} \mathrm{l}$ acre $=0.4047$ ha.

${ }^{y}$ The weighted mean was calculated using the median point of the categories. 
Table 3. Summary information of marketing channel utilization based on surveys of strawberry growers in Pacific Northwest North America in 2017-18 $(\mathbf{n}=32) .^{\mathrm{z}}$

\begin{tabular}{lcccr}
\hline Observations (no.) & British Columbia & Oregon & Washington & All \\
\hline Broker & 0 & 3 & 4 & 7 \\
Direct sales & 6 & 9 & 8 & 23 \\
Grocery/retailer & 3 & 5 & 3 & 11 \\
Export & 0 & 1 & 1 & 2 \\
Institutions & 2 & 4 & 1 & 7 \\
Processors & 1 & 8 & 3 & 12 \\
Others & 0 & 1 & 1 & 2 \\
\hline
\end{tabular}

${ }^{\mathrm{z}}$ The rows are not mutually exclusive because a grower could use multiple channels to sell strawberry.

This high percentage of growers already targeting the fresh market indicates that the sample of growers are already starting to transition to the fresh market or have already done so. Half of our respondents had more than 20 years of experience as the decision maker for their strawberry operation. On average, OR farms had the largest operations, with 70.3 acres per grower compared with 34.2 acres for Washington and 15.1 acres for British Columbia farms.

MARKETING. Marketing channels varied among strawberry growers in the three locations (Table 3; note that channels are not mutually exclusive because a grower could use multiple channels to sell strawberry). The four most frequently mentioned channels used by British Columbia and Oregon strawberry growers were direct sales to consumers, grocery retailers, institutions/restaurants (including schools and hospitals), and processors. Washington growers used direct sales to consumers and grocery retailers, but differed from other growers in that they were more likely to use multiple marketing channels, including brokers and processors, to sell strawberry. Only Oregon and Washington growers exported strawberry. Overall, direct sales to consumers was the primary marketing channel for PNW strawberry growers surveyed in this study. Processors are less likely to contract with small-scale growers, so growers targeting processing markets are fewer in number but are more likely to be larger farms; growers using direct sale markets are more numerous and smaller in size (Dunn et al., 2005).

GROWER PREFERENCES FOR STRAWBERRY TRAITS. Tables $4-8$ present the ordered probit model results for traits estimated by cluster. The first three columns are the estimated coefficients and the last three columns are pairwise $t$ test comparisons of trait coefficients across regions. Because of the nonlinearity of the estimation procedure, the coefficients do not give the marginal effects but are simpler to present because the marginal effects are scenario specific. However, the signs and magnitudes of the $\mathrm{co}^{-}$ efficients are useful in identifying the priority ranking of the traits. A positive significant coefficient indicates that the trait was more highly ranked by growers in the first region than by growers in the second region. A negative significant coefficient indicates the opposite. The number of observations used in model estimation differs across trait clusters because of the difference in the number of individual traits within each trait cluster.

GROWER PREFERENCES FOR FRUIT QUALITY. Grower preferences for strawberry fruit quality traits differed across regions (Table 4). For British Columbia growers, external appearance free of defects was the most important quality trait for a successful cultivar, followed by flavor, skin color, firmness, size, sweetness, and extended shelf life at retail. For Oregon growers, the most important quality trait was flavor, followed by sweetness, internal color, skin color, size, external appearance free of defects, and firmness. For Washington strawberry growers, the most important fruit quality trait was flavor, followed by size, internal color, firmness, sweetness/tart balance, skin color, and sweetness.

Pairwise $t$ tests were used to identify significant differences in preferences across locations (Table 4). For growers in Oregon and Washington, flavor-related traits were of greater importance than appearance for successful cultivars, whereas British Columbia growers favored appearance over flavor. The significant differences in rankings of traits related to low drip loss after freezing and thawing, ease of cap removal, and attractiveness may be due to regional differences in target markets. Ease of cap removal is an important trait for the processing market (Finn et al., 2014), so it is not surprising that British Columbia growers (whose target market is exclusively fresh market; Table 2) ranked this trait as less important than Oregon and Washington growers. In general, $\mathrm{PNW}$ growers considered flavor, size, firmness, and skin color to be important quality traits, a finding that concurs with a previous study of U.S. strawberry growers (Yue et al., 2014).

GROWER PREFERENCES FOR BIOTIC AND ABIOTIC RESISTANCE. Because susceptibility to diseases, insect pests, and plant stress negatively affects production outcomes, growers' rankings of disease, insect pests, and plant stress resistance/tolerance in cultivars are an indication of the grower's perception of the effectiveness of existing management tools for these problems. Overall, within the disease, insect pest, and stress factor clusters, strawberry growers did not identify common most important traits across locations, which shows that the PNW strawberry industry faces different challenges because of differences in climate, soil, and cultural practices.

There were regional differences regarding the most important diseases affecting PNW strawberry growers (Table 5). British Columbia growers ranked powdery mildew (Podosphaera aphanis var. aphanis) as the most important disease, followed by botrytis flower blight and fruit rot (Botrytis cinerea). Oregon growers ranked botrytis flower blight and fruit rot as most important, followed by red stele (Phytophthora fragariae var. fragaria) powdery mildew, and virus diseases, whereas anthracnose (Colletotrichum sp.), fusarium (Fusarium oxysporum), and charcoal rot (Macrophomina phaseolina) were the least important. Washington growers ranked phytophthora crown rot (Phytophthora cactorum) as most important, followed by red stele; charcoal rot was least important, preceded by common leaf spot (Mycosphaerella 


\section{Production and Marketing Reports}

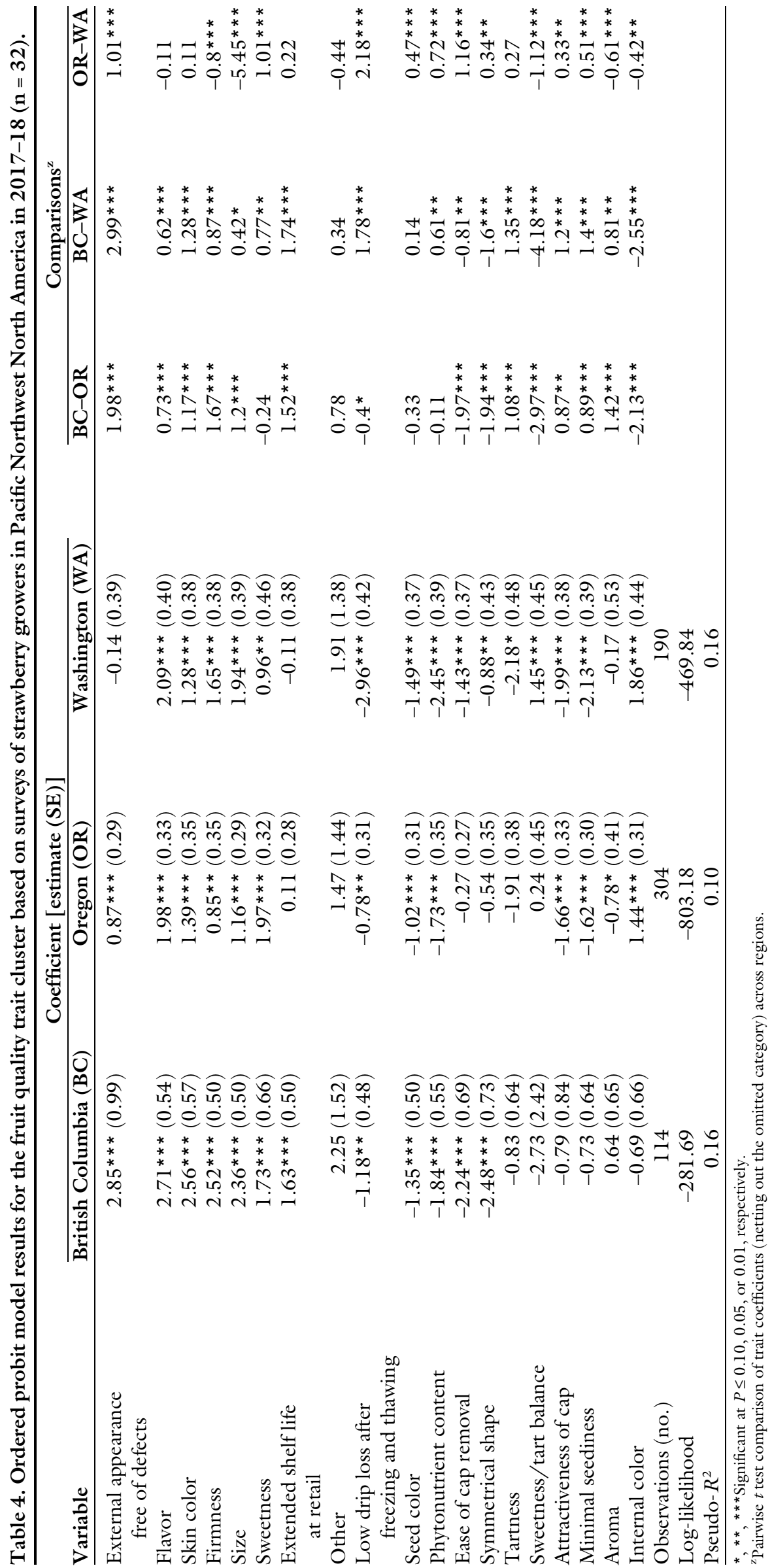


Table 5. Ordered probit model results for disease trait cluster based on surveys of strawberry growers in Pacific Northwest North America in 2017-18 $(n=31)$.

\begin{tabular}{|c|c|c|c|c|c|c|}
\hline \multirow[b]{2}{*}{ Variable } & \multicolumn{3}{|c|}{ Coefficient [estimate (SE)] } & \multicolumn{3}{|c|}{ Comparisons $^{\mathrm{z}}$} \\
\hline & British Columbia (BC) & Oregon (OR) & Washington (WA) & BC-OR & BC-WA & OR-WA \\
\hline Powdery mildew & $1.98 * * *(0.55)$ & $1.35 * * *(0.31)$ & $0.11(0.35)$ & 0.63 * * & $1.87 * * *$ & $1.24 * * *$ \\
\hline Other & $-0.87(0.69)$ & $-0.67(0.54)$ & $-0.25(0.34)$ & -0.2 & $-0.62 * * *$ & -0.42 ** \\
\hline Fusarium & $0.30(0.37)$ & $-0.53 *(0.29)$ & $-0.35(0.36)$ & $0.83 * * *$ & $0.65 * * *$ & -0.18 \\
\hline $\begin{array}{l}\text { Charcoal } \\
\text { rot/macrophomina }\end{array}$ & $-0.77(0.49)$ & $-0.84 * * *(0.29)$ & $-1.22 * * *(0.36)$ & 0.07 & $0.45 * * *$ & $0.38 * *$ \\
\hline Anthracnose & $-0.50(0.52)$ & $-0.84 * * *(0.32)$ & $-0.99 * *(0.42)$ & 0.34 & $0.49 * * *$ & 0.15 \\
\hline $\begin{array}{l}\text { Phytophthora crown } \\
\text { rot }\end{array}$ & $-0.11(0.52)$ & $0.17(0.30)$ & $1.04 * *(0.44)$ & -0.28 & $-1.15^{* * *}$ & $-0.87 * * *$ \\
\hline Red stele & $0.21(0.49)$ & $1.58 * * *(0.30)$ & $1.16 * * *(0.36)$ & $-1.37 * * *$ & $-0.95 * * *$ & $0.42 * * *$ \\
\hline $\begin{array}{l}\text { Black root rot } \\
\text { complex }\end{array}$ & $-0.12(0.52)$ & $0.42(0.34)$ & $-1.09 * * *(0.40)$ & $-0.54^{*}$ & $0.97 * * *$ & $1.51 * * *$ \\
\hline Observations (no.) & 70 & 224 & 140 & & & \\
\hline Log-likelihood & -171.66 & -445.99 & -345.17 & & & \\
\hline Pseudo- $R^{2}$ & 0.07 & 0.11 & 0.07 & & & \\
\hline
\end{tabular}

$*, * *, * *$ Significant at $P \leq 0.10,0.05$, or 0.01 , respectively.

${ }^{\mathrm{z}}$ Pairwise $t$ test comparison of trait coefficients (netting out the omitted category) across regions.

fragariae), black root rot complex, anthracnose, and plant-parasitic nematodes. This finding that the importance of major diseases differs by region is consistent with observable differences in climate and growing conditions across the regions.

The most important insect pests for strawberry growers also differed across regions (Table 6). For British Columbia growers, aphids [shallot aphid (Myzus ascalonicus) and strawberry aphid (Chaetosiphon fragaefolii)] were the most important insect pests, followed by lygus (Lygus sp.), two-spotted spider mite (Tetranychus urticae), and western flower thrips (Frankliniella occidentalis). Oregon growers ranked spotted wing drosophila (Drosophila suzukii) as most important, followed by slugs (Arion sp.) and aphids. Leafrollers [strawberry leafroller (Ancylis comptana fragariae) and western strawberry leafroller (Compsolechia fragariella)] and strawberry whiteflies (Trialeurodes packardi) were less important. Washington growers ranked root weevils (Otiorhynchus sp.) as most important, followed by slugs and thrips. Strawberry crown moth (Synanthedon bibionipennis) and strawberry whiteflies were less important.
For plant stress tolerance factors needed for a successful cultivar (Table 7), British Columbia growers ranked heat tolerance as the most important and drought resistance as the least important challenge. Oregon growers ranked rain damage tolerance as most important, followed by frost tolerance, heat tolerance, and winter cold hardiness. Washington growers ranked winter cold hardiness as most important and indicated that ultraviolet radiation was least important.

For the other plant factor cluster (Table 8), British Columbia growers ranked consistent fruit quality throughout the season as most important, followed by durability (i.e., plant remains productive with good fruit quality over 2 or more years) and high yield, whereas a balance of vegetation and fruit production was least important for a successful cultivar. Oregon growers ranked high yield as the most important plant factor, followed by consistent yield throughout the season, consistent fruit quality throughout the season, durability, and picking efficiency. By contrast, the balance of vegetation and fruit production was considered less important by Oregon growers. Washington growers ranked consistent fruit quality throughout the season as most important, followed by high yield, durability, and extended harvest season, whereas plant canopy was less important. Consistent fruit quality throughout the season, plant durability, and high yield were important traits for PNW strawberry growers in all regions.

Cluster-level modeling. The cluster (group of traits)-level model was estimated with the regions combined and included interaction terms for all clusters. The region British Columbia served as the base trait region (Table 9). Fruit quality was ranked as the most important trait cluster, followed by disease resistance/tolerance and insect or other pest resistance. Yue et al. (2014) similarly found fruit quality components were rated as high importance for successful strawberry cultivars among California, Florida, Michigan, and Oregon growers. Consumer preference studies likewise show that fruit quality attributes including freshness, flavor, texture, and size are important (Colquhoun et al., 2012). Marketing intermediaries also value size, flavor, and firmness (Gallardo et al., 2015). These results suggest that PNW growers are attuned to consumer 
Table 6. Ordered probit model results for insect pest trait cluster based on surveys of strawberry growers in Pacific Northwest North America in 2017-18 $(\mathrm{n}=32)$.

\begin{tabular}{|c|c|c|c|c|c|c|}
\hline \multirow[b]{2}{*}{ Variable } & \multicolumn{3}{|c|}{ Coefficient [estimate (SE)] } & \multicolumn{3}{|c|}{ Comparisons $^{\mathrm{z}}$} \\
\hline & British Columbia (BC) & Oregon (OR) & Washington (WA) & BC-OR & BC-WA & OR-WA \\
\hline Aphids & $1.77 * * *(0.48)$ & $0.73 * * *(0.27)$ & $0.53(0.38)$ & $1.04 * * *$ & $1.24^{* * *}$ & 0.2 \\
\hline $\begin{array}{l}\text { Two-spotted } \\
\text { spider mite }\end{array}$ & $1.08 * *(0.48)$ & $0.27(0.28)$ & $0.46(0.38)$ & $0.81 * * *$ & $0.62^{*}$ & -0.19 \\
\hline Thrips & $0.97 * *(0.48)$ & $0.15(0.28)$ & $0.49(0.37)$ & $0.82 * * *$ & $0.48^{*}$ & $-0.34^{*}$ \\
\hline $\begin{array}{l}\text { Strawberry crown } \\
\text { moth }\end{array}$ & $-0.46(0.53)$ & $-0.28(0.29)$ & $-0.74 *(0.37)$ & -0.18 & 0.28 & $0.46^{* * *}$ \\
\hline $\begin{array}{r}\text { Spotted wing } \\
\text { drosophila }\end{array}$ & $0.49(0.52)$ & $1.28 * * *(0.28)$ & $0.23(0.38)$ & $-0.79 * * *$ & 0.26 & $1.05^{* * *}$ \\
\hline Leafrollers & $-0.43(0.45)$ & $-0.81 * * *(0.31)$ & $-0.58(0.37)$ & $0.38 *$ & 0.15 & -0.23 \\
\hline Log-likelihood & -161.78 & -441.60 & -278.88 & & & \\
\hline Pseudo- $R^{2}$ & 0.10 & 0.07 & 0.06 & & & \\
\hline
\end{tabular}

$*, * *, * *$ Significant at $P \leq 0.10,0.05$, or 0.01 , respectively.

${ }^{\mathrm{z}}$ Pairwise $t$ test comparison of trait coefficients (netting out the omitted category) across regions.

Table 7. Ordered probit model results for plant stress trait cluster based on surveys of strawberry growers in Pacific Northwest North America in 2017-18 $(\mathrm{n}=32)$.

\begin{tabular}{|c|c|c|c|c|c|c|}
\hline \multirow[b]{2}{*}{$\underline{\text { Variable }}$} & \multicolumn{3}{|c|}{ Coefficient [estimate (SE)] } & \multicolumn{3}{|c|}{ Comparisons $^{\mathrm{z}}$} \\
\hline & $\begin{array}{c}\text { British } \\
\text { Columbia (BC) } \\
\end{array}$ & Oregon (OR) & Washington (WA) & BC-OR & BC-WA & OR-WA \\
\hline Heat tolerance & $1.08 * *(0.53)$ & $1.01 * * *(0.31)$ & $-0.09(0.39)$ & 0.07 & $1.17^{*}$ & $1.1 * * *$ \\
\hline Other & $0.09(0.60)$ & $-0.04(0.31)$ & $0.08(0.41)$ & 0.13 & 0.41 & -0.12 \\
\hline Drought resistance & $-1.03 *(0.53)$ & $-0.67 * *(0.29)$ & $-0.71(0.43)$ & -0.36 & -0.32 & 0.04 \\
\hline Frost tolerance & $-0.43(0.65)$ & $1.08 * * *(0.34)$ & $0.21(0.42)$ & $-1.51 * * *$ & -0.64 & $0.87 * * *$ \\
\hline Soil type adaptation & $0.18(0.52)$ & $0.06(0.30)$ & $0.49(0.42)$ & 0.12 & -0.31 & $-0.43 * *$ \\
\hline Ultraviolet damage & $-0.64(0.54)$ & $-0.19(0.32)$ & $-0.91 * *(0.42)$ & $-0.45^{*}$ & 0.27 & $0.72 * * *$ \\
\hline Observations (no.) & 48 & 128 & 80 & & & \\
\hline Log-likelihood & -91.86 & -246.76 & -150.64 & & & \\
\hline Pseudo- $R^{2}$ & 0.08 & 0.07 & 0.09 & & & \\
\hline
\end{tabular}

$*{ }^{* *}, * * *$ Significant at $P \leq 0.10,0.05$, or 0.01 , respectively.

${ }^{\mathrm{z}}$ Pairwise $t$ test comparison of trait coefficients (netting out the omitted category) across regions.

and market intermediary preferences, and this is reflected in how they ranked fruit quality as the most important trait cluster. Grower preferences for individual fruit quality traits varied across region (Table 4 ), and this may be indicative of the different marketing segments that growers may have to adapt to (Wang et al., 2016).

The least important trait cluster was plant stress tolerance (Table 9). The coefficient for insect or other pest resistance/tolerance was not significant, indicating that this trait cluster was not different from other plant factors in importance for British Columbia growers. However, significant interactions indicate that Oregon and Washington growers ranked the insect or other pest resistance/ tolerance trait cluster as less important and Oregon growers ranked plant stress tolerance as more important relative to British Columbia growers.

Previous work has shown that strawberry breeding programs prioritize abiotic resistance and pest and disease resistance as important trait clusters (Gallardo et al., 2012). Furthermore, Yue et al. (2012) found breeding efforts related to consumer preferences, end-use markets, and market price premiums were of lower priority for apple and stone fruit breeders. These findings suggest that there may be a predisposition for breeders to be misaligned in their trait prioritization relative to growers. However, at the cluster level, the results from this survey work suggest that fruit quality and disease resistance/tolerance are more important relative to plant stress tolerance as plant factors. This finding contributes to the literature about strawberry grower preferences. 
Table 8. Ordered probit model results for other plant traits cluster based on surveys of strawberry growers in Pacific Northwest North America in 2017-18 $(\mathrm{n}=30)$.

\begin{tabular}{|c|c|c|c|c|c|c|}
\hline \multirow[b]{2}{*}{ Variable } & \multicolumn{3}{|c|}{ Coefficient [estimate (SE)] } & \multicolumn{3}{|c|}{ Comparisons $^{\mathrm{z}}$} \\
\hline & British Columbia (BC) & Oregon (OR) & Washington (WA) & BC-OR & BC-WA & $\overline{\text { OR-WA }}$ \\
\hline $\begin{array}{l}\text { Consistent fruit quality } \\
\text { throughout season }\end{array}$ & $1.45^{* * *}(0.47)$ & $1.08 * * *(0.31)$ & $1.31 * * *(0.41)$ & $0.37^{*}$ & 0.14 & -0.23 \\
\hline Durability & $0.98 * *(0.47)$ & $0.90 * * *(0.29)$ & $1.08 * * *(0.41)$ & 0.03 & -0.16 & -0.19 \\
\hline High yield & $0.89 *(0.52)$ & $1.91 * * *(0.32)$ & $1.31 * * *(0.42)$ & $-1.02 * * *$ & -0.42 * & $0.6 * * *$ \\
\hline Other & $-0.32(0.77)$ & $0.09(0.32)$ & $0.19(0.39)$ & -0.41 & -0.51 & -0.1 \\
\hline Extended harvest season & $0.21(0.66)$ & $0.31(0.29)$ & $0.71 *(0.41)$ & -0.1 & $-0.5^{*}$ & $-0.4^{* *}$ \\
\hline Open plant canopy & $-0.38(0.49)$ & $-0.42(0.29)$ & $-1.54 * * *(0.44)$ & 0.04 & $1.16^{* * *}$ & $1.12 * * *$ \\
\hline $\begin{array}{l}\text { Consistent yield throughout } \\
\text { season }\end{array}$ & $0.43(0.47)$ & $1.04 * * *(0.30)$ & $0.63(0.39)$ & $-0.61 * * *$ & -0.2 & $0.41 * * *$ \\
\hline $\begin{array}{l}\text { Picking efficiency (open plant } \\
\text { /visible fruit) }\end{array}$ & $-0.27(0.47)$ & $0.74 * *(0.29)$ & $0.09(0.37)$ & $-1.01 * * *$ & $-0.36^{*}$ & $0.65^{* * *}$ \\
\hline Pseudo- $R^{2}$ & 0.10 & 0.10 & 0.12 & & & \\
\hline
\end{tabular}

$*, * *, * *$ Significant at $P \leq 0.10,0.05$, or 0.01 , respectively.

${ }^{\mathrm{z}}$ Pairwise $t$ test comparison of trait coefficients (netting out the omitted category) across regions.

Table 9. Ordered probit model results for overall fruit and plant trait clusters based on surveys of strawberry growers in Pacific Northwest North America in 2017-18.

\begin{tabular}{lc}
\hline Variable & Coefficient [estimate (SE)] \\
\hline Fruit quality & $3.19^{* * *}(0.70)$ \\
Disease resistance $/$ tolerance & $1.88^{* * *}(0.56)$ \\
Insect or other pest resistance & $0.98^{*}(0.51)$ \\
Plant stress tolerance & $-1.74^{* * *}(0.66)$ \\
Other plant factors & $0.07(0.51)$ \\
Oregon $\times$ disease resistance & $-0.68(0.52)$ \\
Washington $\times$ disease resistance & $0.02(0.56)$ \\
Oregon $\times$ insect or other pest resistance & $-1.13^{* *}(0.57)$ \\
Washington $\times$ insect or other pest resistance & $-0.60 *(0.58)$ \\
Oregon $\times$ fruit quality & $-0.98(0.67)$ \\
Washington $\times$ fruit quality & $-0.80(0.71)$ \\
Oregon $\times$ plant stress tolerance & $2.13^{* * *}(0.71)$ \\
Washington $\times$ plant stress tolerance & $1.06(0.75)$ \\
Oregon $\times$ other plant factors & $-0.28(0.54)$ \\
Washington $\times$ other plant factors & $-0.46(0.57)$ \\
Observations $($ no. $)$ & 155 \\
Log-likelihood & -183.54 \\
Pseudo- $R^{2}$ & 0.26 \\
\hline
\end{tabular}

${ }^{*},{ }^{* *},{ }^{* * *}$ Significant at $P \leq 0.10,0.05$, or 0.01 , respectively.

\section{Conclusions}

Changes in consumer tastes and preferences are affecting many industries' production and marketing strategies. We present the case of the strawberry industry in PNW, where the loss of processing markets and increased demand for local food have coincided to encourage growers to transition from a processing to a freshmarket system. There is indication that the industry has or is already in transition, but many of the cultivars currently used were not developed either for fresh-market strawberry production or for the growing conditions in PNW. To facilitate successful transition to the fresh market, research and extension programs need to better understand growers' perceptions of importance of various production and marketing issues. This study found growers identified the fruit quality traits of external appearance free of defects, skin color, size, firmness, sweetness, and flavor as very important traits compared with phytonutrients, seed color, and low drip loss after freezing and thawing for strawberry growers in all locations. Disease resistance/tolerance was the second most important trait cluster, whereas plant stress tolerance was the least. The findings from this study suggest that a focus on fruit quality traits, such as skin color, size, and flavor, and on plant durability and productivity in cultivar development is key to helping PNW strawberry growers transitioning from the processed market to the fresh market. In addition, identification of important traits for each state and province is useful for regional breeding, research, and extension programs focused on developing and management of strawberry cultivars with the shared goal of improved production and fruit quality. These results also highlight that new strawberry cultivars adapted to specific PNW growing areas with improvement in fruit quality for the fresh market, production consistency, and resistance/ tolerance to disease and other pests would be beneficial to the industry. Consumer preference studies would also be valuable in understanding what 
factors influence perception and repeat purchasing behaviors and may be of consideration as breeding programs work to encompass different components into their work.

\section{Literature cited}

British Columbia Strawberry Growers Association. 2019. BC strawberries. 12 Mar. 2019. <https://bcstrawberries. $\mathrm{com} />$.

Carroll, K.A., J.C. Bernard, and J.D. Pesek. 2013. Consumer preferences for tomatoes: The influence of local, organic, and state program promotions by purchasing venue. J. Agr. Res. Econ. 38:379396.

Colquhoun, T.A., L.A. Levin, H.R. Moskowitz, V.M. Whitaker, D.G. Clark, and K.M. Folta. 2012. Framing the perfect strawberry: An exercise in consumerassisted selection of fruit crops. J. Berry Res. 2:45-61.

Dunn, J., J. Harper, and G. Greaser. 2005. Vegetable marketing for small-scale and part-time growers. 15 Mar. 2019. $<$ https://extension.psu.edu/fruit-andvegetable-marketing-for-small-scale-andpart-time-growers $>$.

Feldmann, C. and U. Hamm. 2015. Consumers' perceptions and preferences for local food: A review. Food Qual. Prefer. 40:152-164.

Finn, C.E., B.C. Strik, and P.P. Moore. 2014. Strawberry cultivars for Western Oregon and Washington. Washington State Univ. Ext. Serv. EC 1618. 12 Mar. 2019. <https://catalog.extension. oregonstate.edu/ecl618>.
Gallardo, R.K., D. Nguyen, V. McCracken, C. Yue, J. Luby, and J.R. McFerson. 2012. An investigation of trait prioritization in rosaceous fruit breeding programs. HortScience 47:771776.

Gallardo, R.K., H. Li, V. McCracken, C. Yue, J. Luby, and J.R. McFerson. 2015. Market intermediaries' willingness to pay for apple, peach, cherry, and strawberry quality attributes. Agribusiness 31:259280 .

Greene, W.H. and D.A. Hensher. 2008. Modeling ordered choices: A primer and recent developments. Version 4. New York Univ. Working Paper EC 08-26. 15 Mar. 2019. <https://core.ac.uk/ download/pdf/6641727.pdf>.

Lancaster, K.J. 1966. A new approach to consumer theory. J. Polit. Econ. 74:132157.

Lappo, A., T. Bjørndal, J. FernándezPolanco, and A. Lem. 2015. Consumers' concerns and external drivers in food markets. FAO Fisheries Aquaculture Circ. C1102.

Ostrom, M. and C. Donovan. 2013. Summary report: Farmers markets and the experiences of market managers in Washington State. 15 Mar. 2019. <http://csanr.wsu. edu/wp-content/uploads/2013/11/ WSU-FMMS-report-Nov-2013.pdf>.

Shaw, D.V. and K.D. Larson. 2005. Strawberry plant named 'Albion'. U.S. Plant Patent 16228P3. Filed 29 Jan. 2004. Issued 4 Aug. 2005.

U.S. Department of Agriculture. 2007. Noncitrus fruits and nuts 2006 summary. 3 Apr. 2019. <https://usda.library. cornell.edu/concern/publications / zs $25 \times 846 c>$.
U.S. Department of Agriculture. 2018a. Fruit and tree nut yearbook tables. 15 Mar. 2019. <https://www.ers.usda.gov/ data-products / fruit-and-tree-nut-data / fruit-and-tree-nut-yearbook-tables $/>$.

U.S. Department of Agriculture. 2018b. Noncitrus fruits and nuts 2017 summary. 15 Mar. 2019. <https://www.nass.usda. gov/Publications/Todays_Reports / reports/ncit0618.pdf>.

U.S. Department of Agriculture. 2019. 2017 Census volume 1, chapter 2: State level data. 28 Apr. 2019. <https://www. nass.usda.gov/Publications/AgCensus/ $2017 /$ Full_Report/Volume_1, Chapter_2_US_State_Level/st99_2_ 0033_0033.pdf>.

Wang, J., C. Yue, R.K. Gallardo, V. McCracken, J. Luby, and J. McFerson. 2016. What consumers are looking for in strawberries: Implications from market segmentation analysis. Agribusiness 33:56-69.

Yue, C., R.K. Gallardo, V. McCracken, J. Luby, J.R. McFerson, L. Liu, and A. Iezzoni. 2012. Technical and socioeconomic challenges to setting and implementing priorities in North American rosaceous fruit breeding programs. HortScience 47:1320-1327.

Yue, C., R.K. Gallardo, J. Luby, A. Rihn, J.R. McFerson, V. McCracken, V.M. Whitaker, C.E. Finn, J.F. Hancock, C. Weebadde, and A. Sebolt. 2014. An evaluation of U.S. strawberry producer's trait prioritization: Evidence from audience surveys. HortScience 49:188-193.

Zepeda, L. and C. Leviten-Reid. 2004. Consumers' views on local food. J. Food Distrib. Res. 35:1-6. 